\title{
Complex corrective procedure in surgical treatment of asymmetrical pectus excavatum
}

\author{
Krystian Pawlak, Łuksasz Gąsiorowski, Wojciech Dyszkiewicz \\ Department of Toracosurgery, Poznan University of Medical Sciences, Poznań, Poland \\ Kardiochirurgia i Torakochirurgia Polska 2017; 14 (2): 110-114
}

\begin{abstract}
Aim: In this study we analysed the early and late results of surgical treatment of asymmetrical pectus excavatum using complex surgery combining the Ravitch procedure and the Nuss procedure in the same general anaesthesia.

Material and methods: Eighty out of 938 patients with pectus excavatum operated on between 2002 and 2013, 67 males and 13 females aged 11 to 49 years (mean: 19.2), underwent a complex surgical procedure. During surgery the Nuss procedure was usually performed first (one corrective bar was implanted in 35 patients and two bars were inserted in 45 patients). Because of the unsatisfactory cosmetic effect, additionally the Ravitch procedure was started. The bars were electively removed 3 years after the primary operation.

Results: No mortality was observed in the early postoperative period. Non-life-threatening and transient postoperative complications occurred in 44 (55\%) patients. The most common was pleural effusion (21\%), which in $50 \%$ of patients required pleural drainage. A satisfactory and stable correction effect was achieved in $88 \%$ of cases. Six of those patients required repeat surgery due to recurrence of deformity.

Conclusions: A complex corrective procedure is a successful method of surgical treatment in patients with asymmetrical pectus excavatum and is characterized by satisfactory postoperative results. The use of corrective bars enhances the cosmetic effect. The frequency of early, mostly non-life-threatening postoperative complications after a complex procedure is insignificantly higher than that after the Nuss procedure.

Key words: pectus excavatum, Ravitch procedure, Nuss procedure.
\end{abstract}

\section{Streszczenie}

Cel: W pracy przedstawiono analizę wczesnych i odległych wyników chirurgicznego leczenia asymetrycznej klatki piersiowej lejkowatej przy zastosowaniu operacji złożonej łączącej elementy metody Ravitcha i metody Nussa w tym samym znieczuleniu ogólnym.

Materiał i metody: Osiemdziesięciu spośród 938 pacjentów operowanych od 2002 do 2013 r. z powodu klatki piersiowej lejkowatej, 67 płci męskiej i 13 płci żeńskiej w wieku od 11 do 49 lat (średnio 19,2 roku) poddano leczeniu operacyjnemu metodą złożoną. Podczas zabiegu w pierwszej kolejności zwykle wykonywano procedurę Nussa (u 35 pacjentów wszczepiono jedną płytkę korekcyjną, natomiast u 45 pacjentów dwie). W przypadku niezadowalającego efektu kosmetycznego po wszczepieniu implantów rozpoczynano dodatkowo procedurę Ravitcha. Płytki korekcyjne były planowo usuwane po 3 latach. Wyniki: Nie obserwowano zgonów we wczesnym okresie pooperacyjnym. Powikłania pooperacyjne, w większości przemijające i niegroźne dla życia, dotyczyły 44 (55\%) pacjentów. Najczęstszym objawem był wysięk opłucnowy (21\%), który u 50\% pacjentów wymagał drenażu opłucnej. Zadowalający i stabilny efekt korekcyjny uzyskano w 88\% przypadków. Sześciu pacjentów wymagato powtórnej operacji z powodu nawrotu deformacji.

Wnioski: Operacja metodą złożoną jest skuteczną formą leczenia operacyjnego asymetrycznej i zaawansowanej klatki piersiowej lejkowatej. Cechuje ją wysoki odsetek stabilnych i trwałych korekcji. Wykorzystanie płytek korekcyjnych wzmacnia efekt korekcji deformacji. Odsetek w większości przemijających i niegroźnych dla życia powikłań we wczesnym okresie po operacji metodą złożoną jest nieznacznie wyższy w porównaniu z operacją Nussa. Słowa kluczowe: klatka piersiowata lejkowata, metoda Ravitcha, metoda Nussa.

two corrective methods was reported, the Ravitch procedure is characterized by greater surgical extent [1-5]. However, in some patients especially with advanced or asymmetrical deformities a satisfactory postoperative effect may be difficult to achieve using the Nuss procedure alone $[6,7]$. In pre-

\section{Introduction}

Currently surgical treatment of pectus excavatum by the classical Ravitch method has mostly been replaced by the more efficient and minimally invasive Nuss procedure. Although a comparable rate of good cosmetic results in the

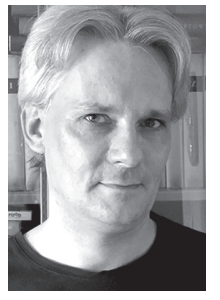

. 
vious reports many modifications of Nuss procedures with modelling of the corrective bar properly to the shape of the chest were described [7, 8]. However, these modelling techniques are effective mainly in younger patients, whereas in adults they may be insufficient because of the rigid and hard chest. Hence these two operative methods (the Nuss procedure and Ravitch procedure) can be combined in one procedure to improve the corrective effect.

\section{Aim}

In this study we analysed the early and late results of surgical treatment of asymmetrical pectus excavatum using complex surgery combining the Ravitch procedure and the Nuss procedure in the same general anaesthesia.

\section{Material and methods}

In 80 out of 938 patients who between 2002 and 2013 were operated on for pectus excavatum at the Department of Thoracic Surgery in Poznan, a complex corrective operation combining the Ravitch method and Nuss method was performed. The entire study group consisted of 67 (84\%) males and 13 (16\%) females with age ranging from 11 to 49 years (medium: $19.2 \pm 7.1$ ). Ten $(13 \%)$ patients suffered from comorbidities, of which mitral incompetence $(n=2)$, bronchial asthma $(n=2)$, epilepsy $(n=2)$ and congenital renal defects repaired after birth $(n=2)$ were the most frequent. The other coexisting diseases (advanced scoliosis and Marfan syndrome) concerned single patients.

Prior to the surgery subjective and objective clinical evaluation was performed in all patients. The chest deformities were assessed in terms of the size, symmetry as well as primary and secondary feature. The size of the deformity was evaluated by the Haller Index calculated based on chest X-rays in two projections - posterior-anterior and lateral view. The Haller index is a quotient of the longest transversal diameter of the inner side the chest and the shortest distance between the posterior surface of the sternum and anterior surface of the vertebra. Asymmetrical deformity was defined when the lowest point of the sternal depression was located outside the medium line of the chest. Secondary deformity concerned those patients in whom an unsuccessful corrective procedure mostly using the Ravitch method was previously performed. Prior to the surgery routine blood tests, chest X-ray (posterior-anterior and lateral view), spirometry and electrocardiography were evaluated in all patients. Chest computed tomography (CT) scan or echocardiography was performed only in a patients with advanced asymmetrical or secondary deformities. Clinical characteristics of deformity and preoperative factors are presented in Table I.

Surgery was performed in general anaesthesia with a single tracheal tube by a modified method first described in 1998 by Nuss et al. [9]. Additionally the epidural continuous infusion of $0.25 \%$ bupivacaine at the level of Th5/Th6 was carried out in all patients and was continued for the 2 following postoperative days. The corrective procedure consisted of retrosternal insertion of a stainless steel bar
Tab. I. Characteristics of pre- and perioperative factors

\begin{tabular}{lc} 
Parameter & $N=80$ \\
\cline { 2 - 2 } Age [years] & $\bar{x} \pm$ SD (min.-max.) \\
\hline FEV $_{1} \%$ & $19.17 \pm 7.1(11-49)$ \\
\hline FVC\% & $93.95 \pm 14.11(52.3-122.9)$ \\
\hline Preoperative Haller Index & $37.57 \pm 12.50(52.4-116)$ \\
\hline Operative time [min] & $150.2 \pm 42.13(45-310)$ \\
\hline Postoperative Haller Index & $2.63 \pm 0.56(1.54-4.96)$ \\
\hline Parameter & Percentage (number) \\
\hline Gender (male) & $83.7 \%(67)$ \\
\hline Secondary deformity & $7.5 \%(6)$ \\
\hline Clinical symptoms: & $38.7 \%(31)$ \\
\hline Pain in chest & $11.2 \%(9)$ \\
\hline Shortness of breath & $32.5 \%(26)$ \\
\hline Coexisting diseases & $12.5 \%(10)$ \\
\hline 1 implemented bar & $43.7 \%(35)$ \\
\hline
\end{tabular}

(BBH Mikromed Ltd) modelled according to the shape of the deformity through two small symmetrical wounds in the mid axillary line under control of bilateral videothoracoscopy. The hinged points, defined as entry and exit points of bar insertion through the intercostal spaces, were chosen with respect to the type and shape of the deformity as described by Park et al. [8]. Additionally, a short stabilizer was inserted on one, usually the left end of the lower bar, to prevent its postoperative rotation. The stabilizer as well as the remaining end of the bar was fixed to the rib by resorbable sutures. The length and number of the implemented bars were selected according to the size of the deformity. One bar was inserted in 35 patients while two bars were implemented in 45 patients. A chest tube was routinely inserted into the right pleural cavity for the 2 following days in all patients. In case of an unsatisfactory corrective effect after the Nuss procedure or in case of instability of the bar threatening its rotation, an additional Ravitch procedure was started. The deformed parasternal costal cartilages were resected subperichondrally on both sides of the sternum by a skin incision the length of the deformity in the midline. Afterward, shortened and sharpened in arrowhead shape ends of the costal cartilages were fixed by nonabsorbable sutures to the lateral surface of the sternum which previously had been placed on the corrective bar. In patients in whom primarily insertion of the corrective bar was impossible or dangerous because of rigid or greatly advanced deformity, the Ravitch procedure was performed first to decompress the retrosternal space. In the final stage of the operation the chest tube was inserted into the right pleural cavity. If pneumothorax developed after chest tube removal, incentive spirometry was begun. In those patients with pneumothorax who had symptoms of dyspnoea limiting postoperative activity and rehabilitation, the chest tube was inserted to the pleural cavity. In case of massive pleural effusion or haemothorax 
Tab. II. Early, 30-day postoperative complications and corrective effect

\begin{tabular}{|c|c|}
\hline \multirow[t]{2}{*}{ Parameter } & $N=80$ \\
\hline & $\begin{array}{l}\text { Percentage } \\
\text { (number) }\end{array}$ \\
\hline Total complications: & $55.0 \%(44)$ \\
\hline Pneumothorax & $20.0 \%(16)$ \\
\hline Haemothorax & $12.5 \%(10)$ \\
\hline Pleural effusion & $22.5 \%(18)$ \\
\hline Pleural tap: & $26.2 \%(21)$ \\
\hline Haemothorax & 7 \\
\hline Pleural effusion & 14 \\
\hline Additional pleural drainage: & $10.0 \%(8)$ \\
\hline Pneumothorax & 2 \\
\hline Haemothorax & 3 \\
\hline Pleural effusion & 3 \\
\hline Fever $>48 \mathrm{~h}$ & $7.5 \%(6)$ \\
\hline Postoperative wound infection & $10.0 \%(8)$ \\
\hline Recurrent deformity & $7.5 \%(6)$ \\
\hline Repeat surgery: & $11.2 \%(9)$ \\
\hline Recorrection & 6 \\
\hline VATS (bleeding into the pleural space) & 2 \\
\hline Revision of infected wound & 1 \\
\hline Satisfactory corrective effect & $87.5 \%(70)$ \\
\hline
\end{tabular}

accompanied by shortness of breath or fever, pleural drainage was used. Otherwise, the fluid was removed by single or repeat pleural tap.

All patients were observed on an outpatient basis at 1 , $3,6,12$ and 24 months after primary surgery and at 1 and 12 months after bar removal. The corrective bars were electively removed in general anaesthesia 3 years after primary surgery.

Satisfactory surgical result was defined when the sternum was in the correct position on lateral chest X-ray and repeat surgery was not needed or the postoperative Haller index was less than 3.0, the patient returned to full preoperative daily activity without discomfort or malfunction and the corrective effect was fully accepted by the patients. Otherwise the surgical results were defined as unsatisfactory.

\section{Results}

The time of operation ranged from 45 to $310 \mathrm{~min}$. Two corrective bars were more often implemented among the patients (Tab. I).

No mortality was observed in the early 30 -day postoperative period. Early postoperative complications, in the majority of cases non-life-threatening and transient, affected $50 \%$ of our patients.

Among all early postoperative complications pleural effusion, affecting $23 \%$ of patients, was the most frequently observed. In majority of those patients the repeat pleural tap was performed to remove pleural fluid. However, pleural drainage was also needed in the remaining 3 patients.

The second most common postoperative complication was pneumothorax, which occurred in $16(20 \%)$ patients. However, only 2 of those patients required pleural drainage. In the remaining 14 patients pneumothorax resorbed spontaneously without need of surgical interventions. All postoperative complications are presented in Table II.

The corrective bars were removed in all our patients between 8 and 59 months (mean: $34.5 \pm 8.3$ ). In 1 patient the corrective bars were removed earlier, 8 months after primary surgery, due to persistent severe pain in the chest limiting daily activity.

A satisfactory and stable corrective effect concerned $88 \%$ of our patients. However, in 6 out of 9 patients who required repeat surgery, re-corrective procedures using the Ravitch method were performed because of an unsatisfactory cosmetic effect after complex surgery. In the 2 other patients repeat surgery using video-assisted thoracic surgery (VATS) and following transfusion of 2 units of blood was required due to postoperative bleeding from the pleural cavity and subsequent anaemia. Moreover, in 1 other patient, postoperative revision of the infected postoperative wound in the midline with debridement of necrotic tissue and removal of the sutures was performed (Tab. II).

\section{Discussion}

By the end of the last century the surgical method described in 1949 by Ravitch was the standard treatment of pectus excavatum [10]. Numerous modifications of that surgical technique were developed mainly to search for the best internal or external sternal stabilisation to achieve stable correction of the chest. However, despite these sophisticated operative techniques, recurrence after the Ravitch procedure in various reports ranged from $2 \%$ to $39 \%$ of patients $[5,11]$. The most prominent reasons for unsuccessful postoperative results after the Ravitch procedure were as follows: coexisting Marfan syndrome, too young patients' age, ineffective internal stabilisation, great surgical extent (necessity of costal cartilages' resection and sternal osteotomy), disfiguring operative wound, and high percentage of postoperative anaemia requiring blood transfusion $[1,11$, 12]. The Nuss procedure, which is devoid of these disadvantages, almost replaced the previously common traditional method of Ravitch and become globally accepted, mostly because of its simplicity, safety and effectiveness. Although the comparable frequency of good corrective effects after both of these surgical methods was previously reported, the Nuss procedure is usually ineffective in patients with asymmetrical deformity $[2,4-6,13]$. Those observations led to combination of both those surgical techniques into one procedure to achieve the best and the most stable correction.

We presented the results of complex surgical correction combining two methods - the Ravitch procedure and Nuss procedure - in treatment of patients with asymmetrical anterior chest wall deformities. This complex surgery usually concerned patients with a rigid and hard chest or those 
with a rotated sternum. The additional indication to use the complex procedure was instability of the corrective bar or high risk of its rotation. In the majority of our patients the ultimate decision to use the additional Ravitch procedure was made intraoperatively. Prior to the surgery each patient was informed about a possible complex operation and signed the consent form. In a few patients in whom the primary insertion of the corrective bars according to the Nuss procedure was dangerous due to rigidity of the chest, the sternum and costal cartilages were realized and elevated first to facilitate retrosternal insertion of the corrective bar. Afterward, the Ravitch procedure was performed. In this way the sternum was embedded on scaffolding of the bars.

Park et al. reported good corrective results of the Nuss procedure in asymmetrical deformities using different techniques of bar modelling with respect to the shape of the chest and proper choice of the hinge points. The authors limited the indications to surgery to the youngest age groups [8]. In our opinion this management may be successful only in younger patients in whom the soft and flexible chest allows a good corrective effect to be achieved. In contrast, in adult patients, due to the rigid and hard asymmetrical chest, despite the sophisticated technique of bar modelling, spontaneous correction of the rotated sternum is usually unsuccessful. In those patients simple elevation of the sternum does not lead to expected corrective improvement and still the uncorrected chest deformity is left. That is why, in our opinion, the use of the additional Ravitch procedure is the only way to achieve good corrective results and not only decompress the mediastinum. In our study a high percentage of satisfactory corrective results was achieved by the use of a complex procedure. However, in 10 of our patients the corrective effects were unsatisfactory. In 6 of those patients a re-corrective operation using the Ravitch method was performed. The other 4 patients did not agree to redo surgery despite unsuccessful primary correction.

The additional Ravitch method allows one to accomplish good correction of the chest as well as derotation and stability of the sternum.

Two bars were most often implanted in our patients. These two corrective bars were used not only to elevate the anterior chest wall but also to correct the upper part of the chest as well as to evenly distribute the pressure forces on the chest. It should be emphasised that the Nuss corrective bar provides much better support for the corrected anterior chest wall by the Ravitch method than implants used in previous modifications (e.g. Adkins strut) [14].

Early 30-day postoperative complications occurred in half of our patients. Most of the complications were transient and non-life-threatening. The frequency of postoperative complications in our study was higher than rates reported after the Nuss procedure (ranging from 8 to 49\%), but comparable to those after the Ravitch procedure (ranging from 25 to $57 \%$ ) [2, 15, 16]. Although most of the postoperative complications were transient, 2 of our patients experienced serious postoperative bleeding from the pleu- ral space which required repeat surgery. In our opinion postoperative bleeding is directly related to surgical extent and may derive from intracostal as well as from mammary artery injuries. The routine intraoperative use of VATS allows one to avoid injury of the mediastinum and lung, but it does not prevent bleeding from the parasternal region after the invasive Ravitch procedure.

Among total number of the early postoperative complications the pleural effusion concerning $23 \%$ of our patients was predominant and in all of those patients with pleural effusion required additional procedures - pleural tap or, less frequently, pleural drainage. Pleural effusion may result from persistent or organised haemothorax, partial atelectasis of the lung or allergic reaction to the corrective bar or chest tube. After single removal of the fluid no recurrence of the pleural effusion was observed.

Postoperative pneumothorax occurred in 20\% of our patients; however, in the majority it resolved spontaneously and did not require additional intervention. Its frequency was similar to that in other reports, ranging from $1 \%$ to as high as 64\% [17-20]. The occurrence of pneumothorax in the early postoperative period could be related to increased volume of pleural space after postoperative elevation of the chest wall or subsequently to connection of both pleural spaces due to bar insertion.

A midline wound infection in the early postoperative period after the Ravitch procedure occurred in 8 patients. The majority of those infections were caused by Staphylococcus MSSA. They were superficial and did not penetrate to the bones. Most of the infected wounds were healed by antibiotic therapy. Only in 1 patient did the infection include the sternal bone and require complex surgical debridement and removal of sutures.

\section{Conclusions}

A complex corrective procedure is a successful method of surgical treatment in patients with asymmetrical pectus excavatum and is characterized by satisfactory postoperative results. The use of corrective bars enhances the cosmetic effect. The frequency of early, mostly non-lifethreatening postoperative complications after the complex procedure is insignificantly higher than that after the Nuss procedure.

\section{Disclosure}

Authors report no conflict of interest.

\section{References}

1. Pilegaard HK, Licht PB. Early results following the Nuss operation for pectus excavatum: a single-institution experience of 383 patients. Interact Cardiovasc Thorac Surg 2008; 7: 54-57.

2. Nasr A, Fecteau A, Wales PW. Comparison of the Nuss and the Ravitch procedure for pectus excavatum repair: a meta-analysis. J Pediatr Surg 2010; 45: 880-886.

3. Lam MW, Klassen AF, Montgomery CJ, LeBlanc JG, Skarsgard ED. Quality-oflife outcomes after surgical correction of pectus excavatum: a comparison of the Ravitch and Nuss procedures. J Pediatr Surg 2008; 43: 819-825. 
4. Davis JT, Weinstein S. Repair of the pectus deformity: results of the Ravitch approach in the current era. Ann Thorac Surg 2004; 78: 421-426.

5. Kang CH, Park S, Park IK, Kim YT, Kim JH. Long-term surveillance comparing satisfaction between the early experience of Nuss procedure vs. Ravitch procedure. Korean J Thorac Cardiovasc Surg 2012; 45: 308-315.

6. Jaroszewski D, Notrica D, McMahon L, Steidley DE, Deschamps C. Current management of pectus excavatum: a review and update of therapy and treatment recommendations. J Am Board Fam Med 2010; 23: 230-239.

7. Luu TD, Kogon BE, Force SD, Mansour KA, Miller DL. Surgery for recurrent pectus deformities. Ann Thorac Surg 2009; 88: 1627-1631.

8. Park HJ, Lee SY, Lee CS, Youm W, Lee KR. The Nuss procedure for pectus excavatum: evolution of techniques and early results on 322 patients. Ann Thorac Surg 2004; 77: 289-295.

9. Nuss D, Kelly RE Jr, Croitoru DP, Katz ME. A 10-year review of a minimally invasive technique for the correction of pectus excavatum. J Pediatr Surg 1998; 33: 545-552.

10. Ravitch MM. The operative treatment of pectus excavatum. Ann Surg 1949; 129: 429-444.

11. Ellis DG, Snyder CL, Mann CM. The 're-do' chest wall deformity correction. J Pediatr Surg 1997; 32: 1267-1271.

12. Fonkalsrud EW, Beanes S, Hebra A, Adamson W, Tagge E. Comparison of minimally invasive and modified Ravitch pectus excavatum repair. J Pediatr Surg 2002; 37: 413-417.
3. Dzielicki J, Korlacki W, Janicka I, Dzielicka E. Difficulties and limitations in minimally invasive repair of pectus excavatum: 6 years experiences with Nuss technique. Eur J Cardiothorac Surg 2006; 30: 801-804.

14. Adkins PC, Blades B. A stainless steel strut for correction of pectus excavatum. Surg Gynecol Obstet 1961; 113: 111-113.

15. Antonoff MB, Erickson AE, Hess DJ, Acton RD, Saltzman DA. When patients choose: comparison of Nuss, Ravitch, and Leonard procedures for primary repair of pectus excavatum. J Pediatr Surg 2009; 44: 1113-1118.

16. Kim do H, Hwang JJ, Lee MK, Lee DY, Paik HC. Analysis of the Nuss procedure for pectus excavatum in different age groups. Ann Thorac Surg 2005; 80: 1073-1077.

17. Shu Q, Shi Z, Xu WZ, Li JH, Zhang ZW, Lin R, Zhu XK, Yu JG. Experience in minimally invasive Nuss operation for 406 children with pectus excavatum. World J Pediatr 2011; 7: 257-261.

18. Mao YZ, Tang ST, Wang Y, Tong QS, Ruan QL. Nuss operation for pectus ex cavatum: a single-institution experience. World J Pediatr 2009; 5: 292-295.

19. Pilegaard HK. Extending the use of Nuss procedure in patients older than 30 years. Eur J Cardiothorac Surg. 2011; 40: 334-337.

20. Aronson DC, Bosgraaf RP, van der Horst C, Ekkelkamp S. Nuss procedure: pediatric surgical solution for adults with pectus excavatum. World I Surg 2007; 31: 26-29. 